\title{
Physical Exam Yes No Indicator
}

National Cancer Institute

\section{Source}

National Cancer Institute. Physical Exam Yes No Indicator. NCI Thesaurus. Code C83070.

An indication of whether a physical exam has been performed. 